\title{
WANITA ASIA DALAM IMAJINASI DIGITAL: KAJIAN LITERATUR ATAS ORIENTALISME
}

\author{
Iman Zanatul Haeri \\ Komunitas Perpustakaan Kandangbuku \\ Email: imanzanatulhaeri91@gmail.com
}

Diterima: 9-11-2016

Direvisi: 5-12-2016

Disetujui: 7-12-2016

\begin{abstract}
Globalization is marked with the spread of Western culture technology products. One of the Western cultural products that are very influential was Hollywood movies. Fictitious narratives produced the some imaginative ideas that apply also on social media communicative as dating site, video porn sites, until advertising. The awareness of imaginative west of geopolitics outside himself or Other revealed by Edward Said in Orientalism. Said that initially examine the practice of West imaginative through Literature opens up the possibility of resumption of studies on other media with the idea that the West has distortion of the knowledge of the East, one considers that the exotic East. Exotic ideas still present in western digital imagination when respect women Asia as the representation of the women of the east. Some Hollywood movies, dating site, video porn sites until the advertisements still presents stereotypes Asian women foreign, mysterious, strange and sensual display. Asian women trapped in exotic role in the Digital imagination space. They exoticiziation and exoticted themselves before the digital public. Globalisation and the development of communications technology in digital imagination proved does not stop the stereotypes against Asian women that they exotic. Thus through digital imagination and the will of the global capitalism, representation Asian women shown, celebrated, promoted and taken advantage of it.
\end{abstract}

Keywords: digital imagination, women Asia, post-Orientalism, exotic.

\begin{abstract}
ABSTRAK
Globalisasi ditandai dengan tersebarnya produk teknologi budaya Barat. Salah satu produk budaya Barat yang sangat berpengaruh adalah film Hollywood. Narasi fiktif tersebut menghasilkan beberapa gagasan imajinatif yang berlaku juga pada media sosial komunikatif seperti situs kencan, video porno, hingga iklan. Kesadaran imajinatif barat terhadap geopolitik di luar dirinya atau other diungkap oleh Edward Said dalam Orientalisme. Said yang pada awalnya mengkaji praktik imajinatif Barat melalui Sastra membuka peluang terbukanya kajian pada media lainnya dengan gagasan bahwa Barat memiliki distorsi pengetahuan tentang Timur, salah satunya menganggap bahwa Timur Eksotis. Gagasan eksotis tetap hadir dalam imajinasi digital Barat ketika memandang Wanita Asia sebagai representasi wanita timur. Beberapa film Hollywood, situs kencan, video porno hingga iklan masih menghadirkan stereotip Wanita Asia yang asing, misterius, aneh dan sensual. Wanita Asia terjebak pada peran eksotisnya dalam ruang imajinasi digital tersebut. Mereka dieksotiskan dan mengeksotiskan diri di hadapan publik digital. Globalisasi dan perkembangan teknologi komunikasi dalam imajinasi digital terbukti tidak menghentikan stereotip terhadap wanita asia bahwa mereka eksotis. Justru melalui imajinasi digital dan kehendak kapitalisme global, representasi wanita asia dipertontonkan, dirayakan, dipromosikan dan diambil keuntungan darinya.
\end{abstract}

Kata kunci: imajinasi digital, wanita Asia, pasca-Orientalisme, eksotis. 


\section{PENDAHULUAN}

Globalisasi merupakan praktik internasional yang hampir tidak mungkin dihindari di belahan dunia mana pun. Scholte $(2002,8)$ menyatakan ada empat definisi globalisasi, yakni internasionalisasi, liberalisasi, universalisasi, dan westernisasi. Meski istilah yang lebih dekat adalah "globalisasi sebagai westernisasi", namun definisi lainnya yang dinyatakan Schole (2002) seperti globalisasi sebagai internasionalisasi, liberalisasi dan universalisasi merupakan bagian dari hegemoni kultural Barat. Kenyataan tersebut, menandakan bahwa globalisasi merupakan sebuah bangunan imajinasi intelektual Barat.

Sejarah kesusastraan Barat seiring dengan perkembangan budaya, politik, dan ekonomi Barat, juga berisi narasi tentang bagaimana "Barat" mendefinisikan dirinya dan memandang sesuatu di luar dirinya. Narasi-narasi sastra dalam bentuk tulisan juga dipraktikkan dalam seni pertunjukan seperti teater. Usia teater Barat hampir sama dengan usia sastra sendiri. Dalam beberapa kesempatan, karya sastra dipertunjungan dalam sekuel drama yang sudah muncul sejak era era Yunani kuno. Teater dalam bahasa Inggris Theater atau dalam bahasa Prancis Theatre sedangkan dalam bahasa Yunani Theatron yang merupakan turunan dari kata 'Theaomai' mengandung makna dengan takjub melihat atau memandang (Melani, 2008, 99). Melalui pengertian tersebut, tontonan sebuah drama yang dihasilkan oleh teks sastra mengalami perubahan media seiring perkembangan teknologi dan zaman.

Sejak ditemukannya fotografi, hingga peralatan yang disebut kamera, maka ruang imajinasi sastra hadir dalam era baru sinematografi. Penemuan kinetostop oleh Thomas Alfa Edison memulai sejarah film atau drama sastra yang hadir dalam motion picture atau gambar bergerak. Visualisasi tersebut tetap menghadirkan "imajinasi kultural barat" pada era baru yang tidak berhenti pada puncak pencapaian sinematografi, namun film yang berisi narasi sebuah drama fiktif maupun nonfiktif yang menghadirkan industri film Hollywood, terus berkembang dan menyebar melalui moda produksi baru, yang disebut dunia digital.
Pada awalnya, sebuah film Hollywood hanya bisa dinikmati melalui layar lebar dan melalui perjanjian tertentu, hadir melalui televisi (The Hollywood Lawyer, 2016). Seperti perjanjian mengenai serial komik Marvel " $X$-Men" yang pernah dirilis menjadi film, kemudian direncanakan menjadi serial televise $20^{\text {th }}$ Century Fox setelah jaringan televisi tersebut memiliki hak adaptasi karakter $X$-Men (McCormick, 2016 Juli 12) (Muvila.com, 2015). Pada perkembangan lanjutan, film-film Hollywood dapat dinikmati melalui website internet. Hal ini ditandai dengan munculnya berbagai film Hollywood yang dapat dinikmati melalui Youtube. Melalui media tersebut, narasi-narasi yang hadir melalui drama film atau video menghasilkan gagasan-gagasan imajinatif maupun mitos yang dalam beberapa kesempatan dipercaya sebagai kebenaran.

Industri film Hollywood, hingga perkembangan teknologi informasi dan komunikasi internet bertanggung jawab untuk sekian stereotip terhadap beberapa budaya di luar dirinya (Keith, 2013; Fahri, 2011), sebagai other. Termasuk pemahaman imajinatif media tersebut pada sebuah lingkup peradaban yang sesungguhnya dinamis, seperti narasi yang tercipta atas benua terbesar di dunia dan paling beragam secara kultural, sebagaimana barat menyebutnya "Timur".

Definisi konstruktif mengenai "Timur" mengalami beragam distorsi yang hampir sebagian besar diisi oleh mitos-mitos yang merugikan. Yakni ketika perempuan Asia dipandang sebagai makhluk oriental yang masih memegang nilai-nilai tradisional bahwa wanita adalah pelayan bagi laki-laki, kebertubuhannya yang eksotis hingga pandangan tentang prilaku seksual wanita Asia. Hal ini semakin terkemuka setelah penerbitan buku Orientalisme oleh Edward Wadie Said, yang mampu menunjukan bagaimana mitos-mitos itu bekerja dalam imajinasi Barat terhadap Timur. Satu bagian kecil dari "Timur" yang imajinatif tersebut adalah bentuk imajinatif barat terhadap wanita Asia, yang ironisnya, tetap muncul di era globalisasi. Seperti kepercayaan bahwa wanita asia dipandang sebagai wanita eksotis. Edward Said, melacak bagaimana distorsi dalam produk Disneyland Aladdin (1994) terhadap tokoh 
Jasmine (Wanita Asia) atau peran inferior penduduk Asia dalam film Hollywood Pearl Harbour (2001), situs kencan, film porno dengan laman "Asian Women" atau wanita Asia hingga iklan yang menunjukan representasi "wanita Asia'. Kesadaran geopolitik tersebut, bergeser pada wacana wanita Asia eksotis, seiring dengan perubahan media dan kepentingan ekonomipolitik Barat di wilayah Asia lainnya, melalui kolonialisme.

Sebagaimana Orientalisme Said memetakan beragam praktik para orientalis dalam prospek bangunan pengetahuan Barat tentang sesuatu di luar dirinya atau Other, maka proses "mentimurkan timur" - sebagai salah satu sikap ideologis tersembunyi--hendak dilacak praktiknya, (1) apakah terjadi proses yang hampir sama; yakni "mengeksotiskan wanita Asia". Sehingga ketika wanita Asia mampu mengembangkan basis eksistensialnya sebagai salah satu manusia di bumi, apakah melalui media-media imajinatif tersebut, wanita asia terus didorong untuk di-eksotiskan dan mengeksotiskan dirinya dalam panggung teater imajinatif Digital Barat (2) Bagaimana praktik imajinasi digital terhadap wanita Asia? Guna melacak benih-benih orientalisme dalam media-media imajinatif tersebut, maka dilakukan pencarian data melalui perkembangan wacana 'wanita asia' di industri Hollywood, dalam 'situs kencan' wanita asia, situs porno terkait halaman "wanita Asia' serta beberapa visualisasi wanita Asia dalam iklan.

\section{ORIENTALISME DAN PASCA ORIENTALISME}

Sejak diterbitkan pada tahun 1978, buku Orientalisme menuai beragam perdebatan di kalangan akademis. Bila memakai cara pandang Said memahami bukunya sendiri, ia membedakan dua jenis pengetahuan. Yakni pengetahuan murni dan pengetahuan politis (Said, 2010, 13). Di antara kedua jenis pengetahuan ini, Said meragukan terdapat independensi pengetahuan murni terhadap pengetahuan politis. Sebab, pengetahuan murni tidak benar-benar independen terhadap situasi politik, hanya saja, pengetahuan murni bersikap pasif terhadap hal-hal politis.

Cara pandang tersebut memperjelas posisi orientalisme dalam khazanah ilmu pengetahuan sosial. Secara garis besar, Said hadir dengan cara membedah karya sastra Barat untuk melacak akar-akar kelahiran orientalisme. Proses pembedahan tersebut membuka tabir praktikpraktik lembaga ilmu pengetahuan Barat beserta imajinasi yang hadir dalam segenap karya sastra Barat, yang cenderung mendukung kepentingan ekonomi-politik Barat.

Sebagian besar temuan Said dalam orientalisme didapatkan dari kajian sastra. Ia melacak akar-akar orientalisme sejak zaman Iliad (Sastra Yunani Kuno sekitar abad ke-6) dan 9 SM), Invasi Napoleon ke Mesir (1798), ketika Orientalisme melahirkan Antropologi dan Filologi (abad ke-19), rivalitas Inggris dan Perancis dalam kajian Orientalisme dan jejakjejak orientalisme kontemporer. Geo-politik yang membuat garis demarkasi antara Barat dan Timur, yang menjadi sebentuk kesadaran dalam orientalisme sudah muncul pada teks era Yunani Kuno, The Persians karya Aeschylus. Ia memaparkan nestapa orang Persia yang dipimpin oleh raja Xerxes ketika kalah berperang dengan Yunani (Said, 2010, 83). Meski orang-orang Persia hanya satu bagian kebudayaan dari sekian banyak kebudayaan yang ada di Asia, namun kekalahan tersebut digeneralisir sebagai kemenangan Yunani (Barat) atas Asia (Timur).

Representasi merupakan konsep kunci dari orientalisme. Representasi, ditafsirkan dalam kalimat yang dikutip Said $(2010,524)$ dari Marx "Mereka tidak dapat merepresentasikan dirinya; mereka harus direpresentasikan." Kedua, representasi tersebut memunculkan dampak orientalisme yang menjadi perdebatan dan bahan koreksi bagi produk pengetahuan barat, maka kajian yang fragmentaris Said tersebut; menyisakan beberapa fragmen lain yang belum diulas tuntas. Kajian ini meliputi wilayah Timur Jauh, Indochina, dan wilayah lainnya. Melalui beberapa catatan, Said menyatakan bahwa kehadiran kajian wilayah tersebut dan hubungan antara Orientalisme dan Subaltern merupakan perkembangan dari "Pasca-orientalisme'. Kajian tersebut diharapkan terus berkembang. Namun di satu sisi, pasca orientalisme memiliki ekses negatif sebagai salah tafsir bahkan penerjemahan yang bermasalah (Said, 2010, 516). Di sisi lain, persoalan-persoalan yang 
timbul oleh kolonialisme dan beragam fenomena setelahnya, dikenal dengan kajian post-kolonial.

Shelley Walia $(2001,20)$ menyebutkan bahwa Said menunjukan bahwa kebenaran bersifat situasional dan politis, ia membuka disiplin sejarah bagi tulisan dan intervensi subaltern. Tanpa sepenuhnya menolak studi empiris, namun upaya Said untuk mengumpulkan sejumlah fakta, dan penekanannya terhadap ikonografi tanda-tanda, simbol-simbol dan bahasa, membantu sejarawan sosial dan sastra untuk mendapatkan wawasan yang lebih luas tentang sejarah. Maka, cukup tepat menempatkan Said sebagai salah satu serial postmodernisme atas posisinya yang cukup "dekonstruktif” dalam sejarah para orientalis.

Pemakaian istilah post untuk postkolonialisme dan postmodernisme menyiratkan sebuah usaha "melampaui" melainkan lebih kepada "kontinuitas" dan "diskontinuitas", yang menitikberatkan pada mode-mode baru dari praktik-praktik kolonialis yang lama (Said, 2010, 543). Sebagaimana diuraikan Medhy Aginta Hidayat (2002) dalam Menggugat Modernisme: Mengenali Rentang Pemikiran Jean Baudrilland, ia menyatakan bahwa postmodern merupakan peralihan yang esensial menuju hal-hal profan. Sebagai sebuah perkembangan zaman, generasi postmodernis telah mengalihkan kajiannya pada Media televisi, iklan dan layar lebar.

Keterlibatan Said dalam perkembangan kajian postmodernisme seperti film, komunikasi visual hingga media massa bisa dilihat dalam beberapa film dokumenter yang skripnya ditulis Said sendiri dengan judul "In The Shadow of The West (1985)", serial film BBC "Exiles: Edward Said (1988)", film dokumenter "The Palestinians"(1988) dibuat Said bersama Ibrahim Abu Lughod, hingga beberapa wawancara dan kuliah umumnya. Dalam beberapa film ini Said lagi-lagi mengurai beberapa stereotip Barat atas Arab-Islam sebagai representasi penghuni gurun yang beringas, berhidung bengkok, suka membunuh dan lainnya.

Salah satu stereotip yang muncul pada era peradaban Islam dan Arab (berada pada puncaknya sekitar abad 1000-1600 M) adalah beberapa kisah imajinatif tentang wanita "Timur" yang eksotis. Ketika itu, Barat memandang Timur dekat atau kekuasaan peradaban Islam (Turki) sebagai suatu kemegahan dan ketinggian yang tak tercapai - dari gosip hingga mitos para pelancong Barat seperti Marcopolo dan lainnya, yang berhasil mengunjungi dunia timur--sehingga menyisakan beberapa mitos tentang kehidupan para Sultan yang dikelilingi oleh selir tanpa busana seperti cover buku Orientalisme versi bahasa Inggris.

\section{EKSOTIS}

Eksotis dalam Cambridge Dictionary diartikan sebagai unusual and exciting because of coming (or seeming to come) from far away. Sedangkan dalam Oxford Dictionary diartikan sebagai originating in or characteristic of a distant foreign country. Kedua kamus tersebut memiliki kesamaan arti bahwa eksotis adalah sesuatu yang ada diluar sana. Pengertian ini serupa dengan cara pandang para orientalis yang memandang Timur sebagai bahan kajian Other atau 'yang lain.' Julia Kuehn (2016, April 5) dalam artikelnya yang berjudul Exotism in $19^{\text {th }}$ Century Literature menunjukkan bahwa pada abad ke 19, eksotisme merupakan bentuk ketertarikan politik dan akademik Barat terhadap literature fiksi Arab seperti kisah One Thousand and One Night, Sinbad The Sailor, Ali Baba, Aladdin dan lainnya.

Menurut Victor Sigalen (2002) yang dikutip oleh Julia Kuehn (2013, 1-2) istilah eksotisme seringkali dikacaukan dengan istilah geografis "tropis". Ia mengklarifikasi bahwa eksotis cannot be about such things as the tropics or coconut trees. Namun dalam kamus (Cambridge Dictionary, 2016), eksotisme memiliki arti yang sama dengan eksotis, dengan penambahan khusus especially a tropical country. Pergeseran makna eksotisme dari kisah fiksi Arab menuju keindahan negara tropis atau wilayah pohon-pohon kelapa merupakan bagian imajinatif dari frame Ideologi Kolonialisme (Kuehn, 2013, 3). Hal ini disebabkan oleh prospek kolonialisme Barat yang semakin berfokus pada wilayah Asia-Timur, Indochina dan Indonesia. Eksotisme sebagai hal asing yang 
jauh nun di sana bergeser pada wilayah geografi yang tropis.

Secara geografis, wilayah tropis yang dimaksud sebagian besar adalah wilayah Asia. Karena Asia sebagai wilayah geografis mencakup pula sebuah representasi Barat tentang Timur. Bila dilacak lebih lanjut, genealogi anasir-anasir para orientalis ketika memandang Timur bermula dari pandangan Barat terhadap beberapa wilayah "di luar dirinya" seperti Aeschylus yang memandang Persia seperti disebutkan sebelumnya (Said, 2010, :2).

Batas-batas wilayah geografis amat kental dengan perkembangan politik, hal ini memisahkan beberapa simbolisasi “Timur yang eksotis' yang selama ini diasosiasikan sebagai "Arab'. Jadi, Arab - dalam pandangan para orientalis — berada pada tataran simbol kemunduran Timur yang terus tercipta dalam beragam karya literatur Barat untuk merepresentasikan Timur Tengah (Said, 2010: 498 \& 502), sedangkan eksotis dicopot begitu saja dari dunia Arab dan Islam, kemudian dilekatkan pada wilayah Asia lainnya. Persoalan ini beriringan dengan prospek kolonialisasi Barat yang mulai memberikan fokus lebih besar terhadap timur jauh (Asia Timur), Indochina dan Indonesia.

Batas-batas tersebut memang berada dalam kenyataan yang tidak stabil. Meskipun terdapat penilaian objektif bahwa semua manusia pada dasarnya sama tanpa perbedaan rasial tersebut, namun persoalannya, stereotip eksotisme, yang merupakan salah satu prinsip orientalisme - tetap terjadi. Yakni ketika Barat menganggap Asia sebagai wilayah eksotis (Larson, 2006, 70; Lee \& Zhou, 2004, 254).

Pandangan imajinatif eksotis tentang Asia berkembang, tidak hanya melingkupi bentang alam tropis, namun menyasar pada penduduknya. Stereotip ini semakin berkembang subur dengan munculnya beragam media visual 'imajinatif' Barat yang terus menggelorakan semangat militan bahwa penduduk Asia eksotis. Pada awalnya eksotis bermakna asing, namun kemudian menjadi suatu nilai estetis (keindahan) tersendiri. Hal tersebut membuat eksotis merasuk ke dalam ranah-ranah estetis sebagai sebuah sifat yang khusus, yang ciri-cirinya dapat dikenali. Salah tafsir yang terus dipupuk melalui tradisi yang tetap dipertahankan seperti itu merupakan nadi orientalisme. Representasi tersebut terakumulasi semakin buruk tatkala, eksotis dipakai untuk memberikan gambaran tentang wanita Asia. Gambaran tersebut adalah sebuah citra visual yang terus diproduksi terusmenerus melalui beragam media.

Secara tidak langsung, produksi visual imajinatif tentang wanita Asia terus dipertahankan oleh panggung besar imajinasi Digital Barat melalui Film Hollywood, situs kencan, situs porno, dan iklan. Tentu saja, perkembangan teknologi fotografi, sinematografi, dan internet dapat melacak bagaimana wanita Asia sebagai sebuah imajinasi digital terus diproduksi. Orientalisme dipakai penulis untuk menganalisis beragam distorsi yang hidup dalam panggung imajinasi Barat tersebut, yang tertuang dalam beragam media; film Hollywood, situs kencan, situs porno hingga iklan yang merepresentasikan wanita Asia.

\section{GLOBALISASI DAN PANGGUNG IMAJINASI DIGITAL BARAT}

Panggung theater imajinasi digital (termasuk Hollywood) mengacu pada beragam visual yang dihadirkan oleh produk teknologi informasi barat-yang menyajikan wanita Asia kepada khalayak publik. Perkembangan industri Hollywood dan era digital yang ditandai munculnya World Wide Web atau disingkat www menjadi ruang baru untuk mengkaji bagaimana stereotip-stereotip yang muncul terhadap wanita Asia. Atau dengan kata lain, merupakan suatu studi yang belum dilakukan Said ke wilayahwilayah tersebut. Sebagai sebuah panggung imajinatif, Hollywood berumur lebih tua dan sudah menghasilkan beragam stereotip terhadap 'Asia' secara umum dan wanita Asia secara khusus.

Imajinasi digital merupakan istilah yang dipakai oleh penulis untuk menunjukkan bahwa keempat media yang dikaji-film Hollywood, situs kencan, situs porno dan iklan-memproduksi daya imajinasi hingga narasi-narasi eksotis. Terdapat perbedaan genealogi antara perkembangan teknologi 
film Hollywood, situs kencan dan situs porno serta iklan. Film Hollywood hadir melalui sejarah perkembangan fotografi hingga kamera dengan gambar bergerak. Situs kencan dan situs porno hadir melalui perkembangan internet. Sedangkan iklan dimulai sejak perkembangan industri cetak (sebagai sebuah pesan komersil, iklan sudah muncul di Cina sejak era Dinasti Song (Hong Cheng, 2009, 26) sekitar abad ke 8). Seiring perkembangan jaman, iklan tidak lagi memanfaatkan industri cetak seperti koran, majalah, famplet, dan lainnya. Kini iklan dapat dinikmati di televisi, media sosial, media online, dan hampir seluruh website komersiil — termasuk situs kencan dan situs porno, menjadikan iklan sebagai cara mengambil keuntungan dari popularitas situs tersebut.

Seiring perkembangan teknologi dan komputerisasi, film Hollywood yang pada awalnya hanya dapat dinikmati melalui layar lebar atau bioskop, kini dapat ditonton melalui internet. Keberadaan YouTube sebagai website penyimpan video terbesar, diisi pula dengan beberapa film Hollywood yang sudah kadaluarsa atau tidak tayang kembali di bioskop. Maka, film Hollywood yang pada awalnya menjadikan ruang layar lebar atau bioskop sebagai ruang konsumsi tunggal, kini film Hollywood masuk ke dalam dunia digital, menjadi bagian dari dunia internet. Film Hollywood, situs kencan, situs porno, dan iklan merupakan representasi imajinasi digital Barat, yang mewakili hasrat, selera, narasi peradaban tersebut terhadap sesuatu di luar dirinya atau other.

\section{HOLLYWOOD}

Hollywood adalah tempat lahir bagi studio film, yang berperan sangat penting bagi citra masyarakat Amerika Serikat di hadapan publik. Studio film yang paling awal dan paling berpengaruh adalah Warner Brothers Picture (pertama kali membuka studio 1918), Paramount (termasuk lima studio film tertua didunia bersama Universal Studio, terbentuk tahun 1912), RKO, Metro Goldwin Meyer, dan $20^{\text {th }}$ Century Fox yang memiliki rumah produksi sendiri. Universal Studio, United dan Columbia Pictures juga dianggap penting meskipun tidak memiliki bioskop sendiri. Sementara Disney, Monogram dan Republik dianggap sebagai generasi ketiga rumah produksi di Hollywood (History Cooperative, 2014).

Sebagai sebuah representasi kultural, Hollywood menghasilkan beragam karya film yang menunjukan bagaimana cara pandang masyarakat Amerika Serikat atau masyarakat Barat terhadap ragam kultural di luar dirinya atau other. Termasuk cara pandang Hollywood melihat masyarakat Asia secara umum dan wanita Asia secara khusus. Film paling tua tentang peran karakter seorang Asia adalah film Charlie Chan yang dirilis pada tahun 1926. Namun, baru mencapai kesuksesan pada tahun 1931 ketika diperankan oleh actor Swedia, Warner Oland (Lepore, Agustus 9, 2010). Karakter "Asia" (Charlie Chan) justru malah diperankan oleh aktor Barat, Oland (kulit putih). Hal ini semakin parah, bahwa setahun kemudian pada tahun 1932, tokoh Cho-cho San diperankan oleh Sylvia Sidney dalam film berjudul Madam Butterfly (1932). Kondisi tersebut sempat dipertanyakan Keith Chow (Newyorktimes, 22 April 2016) dalam opininya dengan judul "Why Won't Hollywood Cast Asian Actor?"

Stereotip terhadap aktor Asia merupakan kenyataan yang 'stabil' dan konsisten terus terjadi dalam industri film Hollywood. Chow memulai dengan film Doctor Strange yang diadaptasi dari komik Marvel dan diproduksi oleh Disney dan Marvel studio, yang menyajikan tokoh laki-laki mistis Tibetian (orang Tibet) yang diperankan oleh Tilda Swinton (aktor kulit putih/Barat). Selanjutnya rumah produksi DreamWorks dan Paramount memberikan peran Cyborg Motoko Kusanagi yang diadaptasi dari anime klasik Jepang "Ghost in The Shell" kepada Scarlett Johansson (aktor kulit putih/Barat).

Deretan orang kulit putih yang memainkan peran "Asia" tetap terjadi, Emma Stone memerankan karakter China-hawaii yang bernama Allison $\mathrm{Ng}$, terus berlanjut hingga film Gods of Egypt dan Exodus: God and King yang didominasi oleh pemeran kaukasian (kulit putih) - ketika memainkan peran Egyptian (orang Mesir). Hal ini bukan tidak disadari, namun sudah menjadi argumentasi umum 
orang-orang Hollywood melalui apriori sinis, menyatakan bahwa para bintang aktor Asia "is because not any of them have a box office track recod." Tentu saja hal ini bertolak belakang dengan keluhan Aaron Sorkin-seorang penulis skrip film-dalam email yang bocor kepada kepala studio film, ia mengaku bahwa; sangat sulit mengadaptasi film Flash Boys (2014) karena tidak ada satupun aktor bintang Asia (Newyorktimes, 22 April 2016).

Pengakuan tersebut membuktikan bahwa berbagai alasan diskriminasi rasial yang ada dalam industri Hollywood bukan berasal dari fakta lapangan, namun berasal dari stereotip, yang tidak mampu melihat dengan jernih kemampuan seni peran dalam seorang aktor tanpa mempertimbangkan asal rasialnya, termasuk aktor Asia. Alasan lain yang sering diulang-ulang adalah argumen bila memakai aktor kulit putih/Kaukasian atau Barat lebih memberikan keuntungan finansial. Hal ini sudah dibantah dengan munculnya film Fast Furious, yang sampai episode ketujuhnya meraup hampir 4 miliar dollar dari seluruh dunia. Faktanya, dalam sebuah studi terbaru Ralph J. Bunche, Center for African American Studies at University of California and Los Angeles yang berjudul "2015 Hollywood Diversity Report: Flipping The Script” (Hunt \& Ramon, 2015) menemukan bahwa film dengan keberagaman ras (seperti aktor dalam film Fast and Furious) tidak hanya menjadi yang tertinggi di box office (Cunningham, 25 Februari 2016), namun menyebabkan hasil yang sangat tinggi untuk investasi bagi studio dan produser.

Persoalan tersebut tidak hanya muncul pada praktik pemilihan pemain atau cast dalam sebuah film. Dalam ajang penyelenggaraan penghargaan nominasi aktor dan film terbaik Piala Oscar atau Academy Award, diskriminasi rasial tersebut tetap terjadi. Piala Oscar pertama kali diselenggarakan pada tahun 1929 di Hotel Hollywood Rossevelt oleh Academy of Motion Picture Arts and Sciences (AMPAS). Ajang penghargaan tersebut secara produktif telah berhasil memberikan penghargaan sebanyak 2.947 kali. Usia ajang penghargaan ini mencapai 87 tahun.
Bulan Januari 2016, tepat ulang tahun Piala Oscar ke 87, David Cox menyatakan bahwa dalam lima tahun terakhir hanya terdapat Sembilan aktor nominasi Piala Oscar non-white (diluar kulit putih). Peristiwa ini menimbulkan polemik, protes hingga tindakan boikot dikalangan artis hingga politikus. Protes dilayangkan David Oyelowo, Lupita Nyong'O, George Clooney, Reese Whiterspoon hingga Barack Obama (Cox, 26 Februari 2016). Puncaknya adalah ramainya hastag \#OscarSoWhite. Di instagram pemakaiannya mencapai 3.849 public post dan sempat menjadi viral di twitter. Kantor berita Huffpost bahkan merilis "57 Facts That Prove The Oscar Are (And Have Always Been) So White" yang menyajikan beberapa fakta menarik, termasuk tentang wanita Asia. Dalam 87 tahun perjalanan penyelenggaraan Piala Oscar, aktor dan artis Asia hanya dua kali memenangkan Piala Oscar dalam 15 kali nominasi. Bahkan satu-satunya aktor (wanita) Asia yang berhasil masuk dalam nominasi Academy Awards adalah Merle Oberon, dan tidak pernah ada satu pun aktor Asia yang berhasil memenangkan kategori best artist (Moreno, 27 Februari 2016).

Zak Keith (2013) dalam artikelnya yang berjudul "Hollywood Asian Stereotypes: Unfair and Pernicius Portrayals of East Asians" menyajikan stereotip dan karakter kontradiktif yang dikenakan pada orang Asia di Hollywood. Stereotip ini muncul, tentu saja berawal dari gagasan rasis. Bahwa orang Asiasebagaimana modus operandi orientalisme bekerja-'ditampilkan sebagaimana Barat memahaminya', bahkan untuk menunjukan sebetapa Asia-nya orang Asia, perlu didikte oleh pemahaman orang-orang Barat. Proses ini terjadi dalam situasi ketika orang-orang Asia, Latin atau Afrika menjadi penduduk minoritas di Barat. Beragam perilaku orang Asia di tanah Barat, yang berprilaku layaknya minoritas, yang terpatronase oleh nilai-nilai serta aturan hukum di sana, menjadikan ekspatriat Asia sebagai manusia yang inferior. Akibatnya, tampilan Asia tampak menjadi lebih rendah dan penuh ejekan.

Beberapa stereotip tentang orang Asia dalam industri Hollywood dirangkum Keith dalam "Top Ten Asian Stereotypes in Hollywood and The Media Used Almost Exclusively". 
Pertama, orang Asia perpetual foreign (orang asing abadi). Kedua, martial arts (lekat dengan seni bela diri). Ketiga, models minority (sebuah model minoritas). Keempat, nerd/geek (kutu buku). Kelima, gendered racism (rasisme gender). Keenam, inferior and subordinate (rendah dan bawahan). Ketujuh, mystic (misterius). Kedelapan, arcvillain, dragon lady or yelow peril (penjahat, wanita naga atau bahaya kuning). Kesembilan, caricature, yellow face bizarre and or unfathomable (karikatur, wajah kuning aneh dan atau tak terduga). Kesepuluh, willing/ deserving targets of open denigration (bersedia atau layak difitnah terbuka). Kesepuluh poin ini hadir dalam 452 film dan acara TV sejak tahun 1919 hingga 2016.

Wanita Asia secara khusus, mendapatkan beberapa stereotip dari poin pertama (orang asing abadi), kelima (rasisme gender) dan kedelapan (dragon lady). Kesemua poin ini terangkum dalam istilah eksotis. Film eksotis pertama disandur dari sebuah pentas teater yang berjudul Madame Butterfly berasal dari cerita pendek yang dikarang oleh John Luther Long pada tahun 1898. Film ini berkisah tentang percintaan antara calon Geisha dan seorang pria warga Amerika Serikat bernama Lieutenant Barton (diperankan oleh Charles Ruggles).

Distorsi semacam ini, hadir melalui Lucy Liu dalam film Ally McBeal (1997) dan Charlie's Angel (2000). Wanita Asia disajikan dalam bentuk ketertarikan seksual kepada laki-laki berkulit putih (Kaukasian) dan selalu saja berpasangan dengan laki-laki berkulit putih. Tentu saja dengan menyiratkan bahwa hubungan ini bersifat penaklukan dan dominasi terhadap wanita Asia. Bahkan dalam beberapa tampilan imajinatif, wanita Asia diasosiasikan lebih tertarik terhadap laki-laki berkulit putih ketimbang laki-laki Asia (Asian male), meski laki-laki berkulit putih tersebut telah menyakiti hatinya seperti dalam film The World of Suzie Wong (Keith, 2013). Gambaran imajinatif terhadap wanita Asia yang dihasilkan oleh Hollywood menentukan peningkatan faktor interested (ketertarikan) pria terhadap wanita Asia.

\section{SITUS KENCAN}

Dailymail merilis penelitian-yang datanya - berasal dari Facebook Dating App (aplikasi kencan facebook) bernama Are You Interested (AYI) tentang persoalan rasial dalam hubungan romantika (percintaan). Penelitian tersebut mengkaji 24 juta hubungan heteroseksual (pria kepada wanita dan wanita kepada pria). Melalui kategori rasial pria dan wanita yang berkulit putih, hitam, Asia, dan Latin. Studi tersebut menemukan bahwa banyak wanita berkulit putih, Asia, Latin lebih tertarik terhadap pria berkulit putih. Sedangkan kebanyakan pria berkulit hitam, putih, dan latin lebih tertarik terhadap wanita Asia. Hasil lainnya, pria Asia cenderung lebih tertarik terhadap wanita Latin. Penelitian tersebut menunjukkan satu hal yang penting bahwa hampir kebanyakan pria berbagai ras tersebut lebih tertarik terhadap wanita Asia (Dailymail, 21 November 2013).

Hasil penelitian tersebut menunjukkan bahwa para pemakai aplikasi tersebut memiliki ketertarikan yang sangat tinggi terhadap sosok wanita Asia. Sosok tersebut bukan keadaan riil di lapangan, namun sebuah hasil perangkat imajinatif yang terus diproduksi, sebagaimana selera pasar. Bagaimana pun, situs kencan merupakan bagian dari sebuah industri informasi digital. Di dalamnya, citra visual yang hadir untuk mendorong hasrat selera para pengguna aplikasi tersebut menjadi bahan pertimbangan untuk memilih pasangannya. Permintaan yang meningkat atas wanita Asia dalam situs kencan tersebut tidak searah dengan keberhasilan menjalin hubungan tanpa tendensi "wanita Asia eksotis". Beberapa wanita Asia yang pernah menggunakan situs kencan ini mengeluh akan 'terlalu besarnya fantasi seksual dan rasisme gender' terhadapnya. Laporan ini sempat ditulis Chelsea Hawkins dalam artikel yang berjudul "We Need To Talk About the Big Problem with Online Dating for Asian Women" di laman mic. com. Beberapa testimoni wanita Asia yang sempat dirangkum adalah:

\footnotetext{
" $i$ 've tried online dating ... before permanently deleting my account after receiving little more than creepy (and sometimes dowright revolting) messages"
} 
"I've received my fair share of doozies, including questions about my personal hygene because of my race... (as well as) questions about what $i$ do in the bedroom or about my body parts."

"I didn't feel safe on these sites. I felt really exposed. Especially as an Asian women, you put your picture up there and suddenly like 'Asian fantasy' would come up" (Hawkins, 7 Januari 2015)

Imajinasi digital atas wanita Asia terus diproduksi tanpa henti sampai menyentuh ruang-ruang fantasi yang bentuknya sudah tidak nyata. Sehingga wanita Asia dipaksa untuk meng'eksotis-kan dirinya di hadapan publik digital. Artinya, wanita Asia yang bahkan sudah teridentifikasi dengan ciri-ciri eksotis, tetap mengalami ketidaksempurnaan permanen sebagai wanita Asia. Sebab sifat dari imajinasi digital 'terakumulatif' dan 'menggandakan' sifat idealnya. Sebagai contoh, hadirnya K-Pop sebagai budaya pop baru yang menjadi sorotan dunia-bahkan dunia barat, membuat wanita "Korea" menjadi primadona baru di situs kencan Asia. Hal ini disampaikan oleh Lena (bukan nama asli), seorang wanita Cambodian-American (campuran Kamboja-Amerika) yang tetap dipandang 'kurang Asia', hanya karena ia tidak mengaku orang Korea. Ia menyatakan "i felt unwanted of unattractive because $i$ wasn't really a Korean Girl" (Hawkins, 7 Januari 2015).

Hal ini membuat wanita Asia tidak dapat menampilkan 'dirinya' sebagaimana adanya secara individual ataupun kultural, karena beberapa stereotip tentang wanita Asia merupakan gambaran imajinatif yang tidak nyata - wanita Korea tidak pernah ada mengingat giatnya trend operasi plastik wajah di sana (CBS News, 28 September 2015). Namun, sebagai cara menampilkan diri di hadapan dunia digital, situs kencan mengarahkan wanita Asia pada stereotip-stereotip tersebut. Eksotisme sebagai sesuatu yang asing, menjelma menjadi 'wanita Asia seharusnya'.

\section{PORNOGRAFI WANITA ASIA}

Karen Eng menyatakan bahwa, "The Fantasy Asian is Intelligent yet pliable, mysterious yet ornamental ... perpetually pre-pubescent-ageless dan petite ... she comes from a culture where women traditionally serve men" (Sharp, 3 Maret 2010). Eksotisme sudah melebarkan arti inherennya pada objek 'wanita Asia' sebagai wanita yang masih menjunjung tinggi nilai budaya tradisional wanita melayani pria. Fantasi semacam ini hadir dalam beberapa media komunikasi yang mengukuhkan keberadaan imajinasi digital tentang wanita Asia 'seharusnya'. Wanita Asia sebagai tampilan visual, sebagai imajinasi digital dan sebagai sebuah kebertubuhan yang memuat polemik panjang tentang cara pandang-dunia pria atau maskulin - melihat wanita secara luas merupakan perdebatan yang hadir dalam wacana pornografi.

Andrea Dworkin (Syarifah, 2003, 24) menyatakan bahwa pornografi, sesuai dengan akar katanya; porne (pelacur kelas rendah) dan grafos/grafis (gambaran) - adalah gambaran dan kegiatan seksual yang dilakukan oleh para porne atau pelacur kelas rendah. Pengertian pornografi meluas dengan sendirinya seiring dengan perkembangan budaya manusia memahami bagaimana perempuan dan tubuhnya 'harus' ditampilkan. Syarifah menunjukan bahwa filsuf Barat sejak Plato, Rousseau, Schopenhauer, hingga Sastre memiliki bias-bias maskulinitas dalam pemikirannya (Syarifah, 2003, 107-18).

Kemunculan Simon de Beauvoir sebagai eksponen feminis Barat pada tahun 1960an-bersama Sastre dan Michael Foucault (Said, 2000, 42-3) --mencoba melakukan dekonstruksi terhadap sejarah filsafat Barat, bahwa selama itu, apa yang dihasilkan peradaban Barat-manusia universal, objektif, bebas nilai, kekal—hanyalah sebuah perspektif maskulin. Apa yang dimaksud manusia dengan man adalah cara pandang yang memandang manusia ideal, bahwa manusia yang dimaksud itu laki-laki. Eksploitasi berlebihan terhadap 'tampilan visual wanita' merupakan suatu diskriminasi gender, bahwa wanita diartikan sebagai bagian dari alam, bahwa fungsi produksinya yang menghasilkan manusiamanusia (melahirkan), dan organ tubuhnya yang dianggap tidak lengkap karena tidak memiliki penis (Jacques Lacan menyebutnya dengan istilah Phalus), menyebabkan wanita dalam pornografi, 
kurang lebih, layak dieksploitasi seperti manusia mengeksploitasi alam; mengeruk, mengambil sesuatu darinya, 'menampilkannya' sesuai hasrat manusia, untuk kepuasan. Berita buruknya, bahwa eksploitasi terbesar dalam 'pornografi' bukan tubuh laki-laki, namun kebertubuhan wanita.

Melalui pengertian tersebut, pornografi menjadi sebuah dunia hasrat seksual. Sejarah manusia mengukir bagaimana representasi erotis di masa Paleolitikum, manusia memahat batu dan kayu menjadi buah dada besar dan wanita hamil. Kemudian pada era Yunani Kuno, sudah terdapat patung-patung telanjang laki-laki dan wanita secara khusus. Pada abad ke-2, di India sudah terdapat buku panduan seksual yang bernama Kamasutra - kajian pornografi kekinian menyebutnya sebagai pornoteks. Di Jepang pada era Morumachi (1336-1573) dikenal seni lukis yang menggambarkan hubungan seksual melalui media kayu/kertas, dinamakan Shunga. Tentu saja diberbagai belahan dunia lainnya, pornografi sebagai ekspresi seksual hadir melalui beragam media.

Pornografi kemudian memanfaatkan teknologi video. Pada tahun 1896 di Perancis dibuat film erotis pertama berjudul Le Choucher De La Mariee (1896) yang diproduksi oleh Eugene Pirou. Melalui hubungan perdagangan internasional dan tersebarnya teknokultural Barat, tersebarnya film Hollywood pada era "American Dreams" pada era 1970an, dan hadirnya internet di berbagai belahan dunia mempercepat konsumsi video porno. Beberapa studi tentang konsumsi video porno menunjukan hal tersebut.

Pertama, setiap detik, 307.564 dollar dibelanjakan untuk konsumsi pornografi. Kedua, laman website pornografi terbesar dihasilkan oleh negara Amerika Serikat (Barat) dengan total 244.661.900 laman, disusul Jerman, UK, Australia, posisi kelima ditempati Jepang dan seterusnya. Keterangan tersebut searah dengan fakta bahwa rumah produksi pornografi terbesar berasal dari Amerika Serikat (AS) dengan beberapa situs porno kawakan seperti vivid entertainment, Hustler, Playboy, Wicked picture, Red Light District (Family Safe Media, 2006).
Semua situs porno tersebut memuat laman "Asian women" sebagai salah satu andalan produk video pornonya. Di luar itu, sebuah iklan situs pornografi merilis situs pornografi wanita Asia terbaik mulai dari Asian Porn.com, Tube8 Asian. com, Asianxhumster.com, Japaneseehotporn. com, erito.com, AsianEporner.com hingga iYoTube.com (Gotblop, 2016).

Thuy Linh Tu dalam Asian America. Net: Ethnicity, Nationalism, and Cyberspace menyebutkan bahwa salah satu fenomena kesuksesan the online adult industry adalah dengan menghadirkan tubuh (wanita) Asia. Melalui bisnis multi-miliar dollar tersebut, situs porno wanita Asia berperan dari 25 - 30 persen dari fenomena kesuksesan tersebut. Fenomena ini terkait pula dengan ekses ideologi kapitalisme hingga komodifikasi dan seksualitas tentang tubuh yang rasis. Ia menyebutkan (Lee \& Wong, 2003, 267-8):

"On Pornographic sites, the bodies, as real
as it can be, is in fact what is beaing offered;
its gender and race are not only legible,
but the main draw. What it sells is not just
flesh-digital or "real"-but much more
precisely the underlying histories and myth
that such Bodies invoke. Asian porn sites
trade on long standing (certainly predigital)
and relatively unimaginative assumption
aobut Asian women; that they are exotic and
hold limitless sexual knowledge, yet docile
and eager to please. Hardly a Product of the
web alone, they product reflect, recycle, and
make easily avalaible those fantasies already
existing in the social world."

Internet merupakan media bagi pornografi untuk menjadikannya bisnis yang besar dan menguntungkan - terutama video porno, di dalamnya wanita Asia merupakan salah satu page (laman) paling dicari. Beberapa karakteristik yang dicari tidak jauh berbeda dengan imajinasi eksotis yang hadir dalam 'film Hollywood' dan situs kencan', bahwa wanita Asia sebagaimana warna kulitnya yang cokelat atau kadang kuning, sikapnya yang 'menyenangkan dalam hal pelayanan', wanita Asia sebatas seksualitas (Lee \& Wong, 2003:271), yang gambaran tersebut diciptakan melalui imajinasi bahwa wanita Asia eksotis. 
Pada umumnya, peran-peran aktor film porno menonjolkan kebertubuhan seksual yang tabu seperti payudara, alat kelamin (vagina dan penis) yang menjadi anggapan umum sebagai pusat seksualitas manusia. Ketika memasuki industri film pornografi, para aktor tersebut harus memberikan kualitas tambahan terhadap produk-produk pornografinya. Beberapa aktor wanita Asia yang memasuki industri pornografi menunjukan kualitas exotisnya. Complex.com merilis 50 bintang porno wanita Asia terpanas, dengan karakter eksotisnya masing-masing. Mimi Miyagi (Jepang) dikenal memainkan peran eksotis Oriental Dolls. Tie bersaudara; Hayle Le \& Baylee Le (Vietnam) pada urutan 46 dikenal atas beberapa peran eksotis "Mystic". Mai Lin dan Asia Carrera sering memainkan peran eksotis "Dragon Lady". Tia Tanaka, Nautica Thorn dan Charmane Star sering mendapatkan peran Yellow Peril atau Yellow Fever (Gabriel Alvarez, 2011, September 19). Identifikasi Oriental Dolls, Mystic, Dragon Lady dan Yellow Peril atau Yellow Fever merupakan bagian dari wilayah imajinatif eksotisme wanita Asia dalam pornografi.

\section{IKLAN}

Citra yang kasat mata tentang wanita Asia hadir pula dalam beberapa media masa di Barat termasuk iklan. Menurut Kamus Besar Bahasa Indonesia (KBBI), iklan didefinisikan sebagai berita pesanan untuk mendorong, membujuk kepada khalayak ramai tentang benda dan jasa yang ditawarkan; iklan dapat pula berarti pemberitahuan kepada khalayak ramai mengenai barang dan jasa yang dijual, dipasang di dalam media masa seperti surat kabar dan majalah (KBBI, 2 September 2016). Definisi ini terkait sejarah panjang industrialisasi di Eropa/Barat, mengenai ekspansi dagang hingga promosi yang dilakukan oleh kapitalisme. Orientalisme yang diungkapkan oleh Said, menunjukan dengan jelas, bagaimana kepentingan Barat yang tersalurkan melalui ekspansi ekonomi kapitalisme dan kolonialisme, serta corong pembicaranya yang paling halus; iklan.

Sebagai perangkat marketing dari industri, iklan bertanggung jawab atas sekian tendensi eksotis terhadap 'wanita Asia'. Jenn, Seorang aktivis feminis mengungkapkan beberapa tindakan rasis sebuah iklan maskapai Airfrance dan penampilan oriental panggung penyanyi papan atas AS, Ketty Pery (Jenn, 17 April 2014). Bukan kebetulan bila Jenn, menulis bahwa iklan maskapai Airfrance memiliki akses orientalisme, yang membuat wanita Asia sekedar sebuah objek. Sebagai gambaran, iklan maskapai Airfrance berupa perempuan dengan make up oriental (putih, sipit, dan alis yang panjang) memakai kepala barongsai. Model tersebut menyiratkan beberapa stereotip terhadap wanita Asia yang sudah disebutkan; misterius, berkulit kuning, 'asing' - semua ciri-ciri tersebut merupakan signified (Saussure, 1988, 145-150) bahwa wanita Asia adalah eksotis.

Di sisi lain, penampilan Katy Perry yang menggunakan busana geisha, (busana wanita penghibur tradisional papan atas Jepang) dalam suatu pertunjukan musiknya, merupakan suatu bentuk teatrikal atas 'identitas Asia' melalui panggung imajinatif yang dimiliki Barat. Secara teknis, 'geisha/wanita Asia' ditampilkan oleh melalui koreografer, ahli busana dan tata rias yang bekerja dalam 'produk konser Barat'. Identitas wanita Asia tersebut dirampas hak 'representasi dirinya' oleh suatu sebuah mesin pertunjukan yang dikuasai Barat.

Sebuah artikel yang berjudul "Asian Americans Face New Stereotype in Ads" menyebutkan beberapa iklan televisi hingga internet yang memuat beberapa stereotip wanita Asia. Salah satu stereotip tentang wanita Asia adalah sebuah adegan iklan perusahaan IBM (Fahri, 23 Agustus, 2011). Kim Bartel Sheehan dalam buku Controversies in Contemporary Advertising menunjukan hal yang sama terkait benih-benih orientalisme dalam dunia periklanan. Ia memberikan contoh, bagaimana sebuah iklan Velux Skylight yang ingin menunjukan sisi eksotis wanita Asia (Sheehan, 2004, 124); bahwa seorang wanita Asia nampak dragon lady (misterius) atau china doll (boneka porselen). Melalui cara pandang tersebut, maka dapat dipertunjukkan barisan tampilan visual iklan lainnya yang mengandung tendensi bahwa wanita Asia eksotis. 
Gambaran iklan wanita Asia eksotis dengan karakter "Martial Arts" pernah dilakukan aktor wanita Asia Zhang Ziyi untuk iklan produk susu berjudul Goat Milk? Pada foto majalah tersebut, Zhang Ziyi memakai kimono sutera sedang memperagakan gerakan seni bela diri memukul botol berisi susu. Wilson bahkan menambahkan bahwa Perusahaan Laundry sebuah keluarga Cina memanfaatkan stereotip eksotis misterius dengan menambahkan kata "Ancient Chinese Laundry Secret" untuk menarik konsumennya. Iklan sebuah maskapai bahkan menambahkan keterangan "would be under the care of the Singapore Girls" sebagai bagian dari nilai lebih pelayanannya. Dunia periklanan tidak berupaya untuk menghapus sifat rasial terhadap Wanita Asia, justru memanfaatkan dan mempromosikan eksotisme wanita Asia secara eksplioitatif. Ciri-ciri fisik model wanita Asia seperti bertubuh kecil, bermata gelap, rambut dengan poni dan rok dengan belahan telah menjadi prasyarat komersil industri periklanan. Salah satu contoh pentingnya ciri-ciri wanita Asia eksotis tersebut perlu diterapkan dalam dunia periklanan adalah kegagalan seorang model Leslie Kawai pada tahun 1981 dalam "Tournamen of Roses Queen" yang dilakukan oleh sebuah perusahaan bir. Ia diberitahu agar memotong rambutnya supaya memiliki poni, ketika menolak, perusahaan tersebut memilih model lain yang memiliki poni (Wilson., et all 1995, 149-150).

\section{PENUTUP}

Ketika mengadakan survei secara cepat, google adalah pilihan paling tepat untuk mencari objek kata yang dicari. Untuk penelusuran kata kunci "Asian Women", google menyuguhkan 41.500.000 temuan untuk kata tersebut dengan kecepatan 0.79 detik (Asian Women, 29 Agustus 2016). Untuk "related searches" atau kata kunci terkait, terdapat kata kunci Asian women spa, Asian women facts, Asian women for Marriage, Asian women dating, Asian women porn dan lainnya.

Pasangan kata 'wanita Asia' seperti 'seksual, spa, marriage, dating, porn,' merupakan fakta digital tentang aktivitas user internet ketika menggali informasi atau dalam cara pandang ekonomi yang kasar — mengkonsumsi visualisasi digital wanita Asia. Teknologi komunikasi yang seharusnya mampu menghapus bias-bias identitas wanita Asia, malah memproduksi, merayakan hingga mempromosikan identitas eksotis. Kecenderungan melihat wanita Asia sekedar tubuh yang rasis dan imajinasi yang eksotis, hidup subur di dunia digital. Persoalan ini adalah bentuk-bentuk baru kolonialisme didunia pascamodern.

Kajian tentang pascakolonial dan orientalisme tidak bermaksud untuk merayakan ancaman kuno tentang dominasi Barat atas Timur. Pembacaan tersebut tidak hanya mengaburkan upaya-upaya untuk menjunjung tinggi nilai-nilai kemanusiaan dan hak untuk berbudaya, yang sudah berjalan seperti kritik atas modernitas, kritik atas kapitalisme dan kolonialisme, kajian tentang politik identitas dan kajian interaksi budaya yang sering dilakukan oleh sarjanasarjana Barat maupun sarjana Timur. Temuan tentang beragam distorsi terhadap wanita Asia dalam imajinasi digital; film Hollywood, situs kencan, situs porno hingga iklan merupakan upaya pencegahan, agar benih-benih orientalis tidak hidup kembali melalui media teknologi baru.

Wanita Asia dalam Imajinasi Digital menemukan bahwa dalam panggung imajinasi digital Barat terdapat bias orientalisme yang berbentuk eksotisme. Industri film Hollywood yang merupakan bentuk ekspresi kultural Barat berubah menjadi agen penyebar ide-ide rasial hingga supremasi kulit putih tentang ragam budaya 'di luar dirinya'. Wanita Asia dalam industri Hollywood tidak memiliki kuasa atas panggung budayanya sendiri. Sulitnya wanita Asia mendapatkan peran sebagai wanita Asia merupakan bukti bahwa terdapat monopoli atas representasi sebagai wanita Asia. Beragam peran wanita Asia justru banyak dimainkan oleh artis non Asia atau kulit putih. Rentetan film sejak Madam Butterfly (1932) hingga Ghost in The Shell (2016) menunjukkan bagaimana peran wanita Asia justru diperankan oleh aktor kulit putih. Di sisi lain, gambaran wanita Asia dalam industri film Hollywood dipenuhi stereotip bahwa mereka eksotis dengan ciri-ciri kemampuan bela diri, memiliki ketertarikan pada pria kulit putih, 
memiliki sifat yang misterius, aneh dan penurut dalam pelayanan seksual. Hak representasi diri telah dirampas oleh rangkaian imajinatif tersebut sehingga wanita Asia perlu di-Asia-kan sesuai dengan stereotip yang berlaku di Hollywood.

Gambaran wanita Asia eksotis tersebut berpengaruh pada ketertarikan pria secara global lintas rasial. Beberapa temuan menunjukkan bagaimana rangkaian imajinatif tersebut berpengaruh pada ketertarikan terhadap wanita Asia. Situs kencan dari AreYouInterest.com hingga AsianWomenDating.com mencoba memenuhi dan menyajikan wanita Asia kepada publik digital malah menuai banyak persoalan. Situs kencan membuat wanita Asia yang memiliki akun tersebut menerima beragam pelecehan seksual dan beragam kekerasan komunikatif ketika pria user pencari wanita Asia memaksakan "wanita Asia eksotis yang imajinatif" terhadap wanita Asia yang nyata.

Melalui industri Pornografi, gambaran wanita Asia eksotis semakin dilebih-lebihkan. Wanita Asia dalam Pornografi dilekatkan pada peran-peran eksotis dengan perilaku seksualnya yang misterius dan bisa diperlakukan sebagai boneka seks hingga anggapan bahwa wanita Asia memiliki pelayanan seksual khusus terhadap pria kulit putih. Hal ini menutup kemungkinan bahwa wanita Asia bukan sekedar objek seksualitas. Kenyataan tersebut berlaku pula pada citra wanita Asia dalam industri periklanan. Gambaran wanita Asia eksotis seperti misterius, tanpa ekspresi seperti boneka dan memiliki keahlian bela diri merupakan identitas yang terus diproduksi industryi periklanan.

Wanita Asia, perlu dipandang tanpa distorsi-distorsi identitas, yang menjebaknya dalam representasi eksotis. Panggung imajinasi digital Barat seperti Hollywood, situs kencan, pornografi dan iklan membuat wanita Asia terus direpresentasikan dan merepresentasikan dirinya dihadapan publik digital. Representasi eksotis memaksa mereka selalu berlombalomba mengejar gambaran imajinatif tersebut. Orientalisme Edward Said membantu kajian tentang Wanita Asia untuk mengungkapkan bagaimana panggung Imajinasi Digital Barat membangun representasi atas wanita Asia eksotis. Namun, Said tidak berjalan lebih jauh untuk melihat bagaimana respon wanita-wanita Asia sendiri terhadap bangunan imajinatif tersebut.

Panggung Imajinasi Digital Barat tidak murni dikuasai oleh Barat. Panggung tersebut diciptakan oleh Barat, namun tidak dipungkiri melalui transfer teknologi dan pengetahuan serta bebasnya arus investasi, representasi bahwa wanita Asia eksotis menjadi suatu potensi komersil yang dieksploitasi semua pihak, Barat ataupun Timur dan Asia atau Non-Asia. Seperti Hollywood yang menciptakan syistem kompetisi rasial dan diskriminasi gender terhadap Wanita Asia, situs kencan yang menciptakan hubungan tendensi eksotis terhadap wanita Asia, industri pornografi yang memaksa wanita Asia eksotis sekedar seksualitas hingga iklan yang mempertahankan identifikasi eksotis terhadap wanita Asia, hal tersebut merupakan bukti betapa sulitnya melepaskan identitas eksotis terhadap wanita Asia. Pengungkapan tentang eksotisme yang memiliki kecenderungan imajinatif terhadap wanita Asia searah dengan kepentingan untuk meruntuhkan mitos terhadap wanita Asia. Kepentingan ini sekurang-kurangnya membuat kajian tentang wanita Asia dalam imajinasi digital, yang terus dipaksa untuk terus 'dieksotiskan', agar keluar dan meraih kesempatan-kesempatan eksistensialnya sebagai wanita penghuni bumi.

Sejarah manusia adalah sejarah pria dan wanita. Upaya untuk membuka tabir 'eksotisme' wanita Asia dalam imajinasi digital merupakan upaya untuk memberi kesempatan eksistensial kepada wanita Asia untuk hidup sebagai wanita tanpa bayang-bayang other. Manusia memerlukan wadah eksistensial tanpa distorsi hingga stereotip, yang pernah dialami 'Timur'. Belajar dari sejarah orientalisme yang kelam, perangkat imajinasi digital (Hollywood, situs kencan, pornografi, dan iklan) perlu mempertimbangkan bahwa identitas eksotisme yang menjangkit wanita Asia - melalui imajinasi digital- hanyalah sebuah mitos dalam selubung kapitalisme global. 


\section{PUSTAKA ACUAN}

Alvarez, G. (2011, September 9). The top 50 hottest Asian porn stars of all time. Complex.com. Retrieved from http://www.complex.com/popculture/the-top-50-hottest-asian-porn-starsof-all-time/Cheng, Hong. (2009). Advertising and Chinese society: impacts and issues. Copenhagen: Business School Press DK.

Alvarez, G. (2011, September 9). The top 50 hottest Asian porn stars of all time. Complex.com. Retrieved from http://www.complex.com/popculture/the-top-50-hottest-asian-porn-stars-ofall-time/ Adm. (2016).

Chow, K. (2016, April 22). "Why won't hollywood cast Asian actor?" Newyorktimes. Retrieved from http://www.nytimes.com/2016/04/23/ opinion/why-wont-hollywood-cast-asianactors.html? $\mathrm{r}=0$.

Cunningham, T. (2016, February 25). "Movies with diverse casts make more money, study finds" TheWarp. Retrieved from http://www.thewrap. com/movies-with-diverse-casts-make-moremoney-study-finds/.

Farhi, P. (2011, August 23). “Asian Americans face new stereotype in ads". The Washington Post. Retrieved from https://www.washingtonpost. com/lifestyle/style/asian-americans-face-newstereotype-in-ads/2011/08/11/gIQAiMzvZJ_ story.html.

Hawking, C. (2015, January 7). "We need to talk about the big problem with online dating for Asian women". Mic.com. Retrieved from http://m. mic.com/articles/107840//we-need-to-talkabout-the-big-problem-with-online-dating-forasian-women\#yFatRJrg9.

Hidayat, M.A. (2002). Menggugat modernisme: mengenali rentang pemikiran Jean Baudrilland. Yogyakarta: Jalasutra.

Hunt, D. \& Ramon, A.C. (2015). Hollywood diversity report: flipping the script. UCLA: Ralph J Bunche Center for African American Studies.

Kuehn, J. (2014). A female poetics of empire: from Elliot to Woolf. New York: Routledge.

Kuehn, J. (2015, April 5). Exotism in $19^{\text {th }}$ century literature. British. Library.UK Retrieved from https://www.bl.uk/romantics-and-victorians/ articles/exoticism-in-19th-century-literature.

Kuehn, J. (2015, April 5) Exotism in $19^{\text {th }}$ century literature. British. Library.UK Retrieved from https://www.bl.uk/romantics-and-victorians/ articles/exoticism-in-19th-century-literature.

Larson, G. (2006). Media and minorities: the politic of race in news and entertainment. Maryland: Rowman \& Littlefield Publishers.
Lee, R. C \& Wong, S. C. (2003). Asian America.Net: ethnicity, nationalism, cycberspace. New York: Routledge.

Lee, J. \& Zhou, M. (2004). Asian American youth: culture, identity, ethnicity. New York: Routledge.

Melani, B. (Ed.). (2008). Membaca sastra (pengantar memahami sastra untuk perguruan tinggi). Magelang: Indonesia Tera.

McCormick, R. (2016, July 12). Fox is Making an $X$-Men TV Series with Movie Director Bryan Singer. The Verge.com. Retrieved from http:// www.theverge.com/2016/7/12/12169342/fox$\mathrm{x}$-men-tv-series-bryan-singer.

Moreno, C. (Ed). (27 February 2016). “57 facts thats prove the oscar are (and have always been) so white". USA: Huffingtonpost. Retrieved from http://www.huffingtonpost. com/entry/57-striking-facts-that-provethe-oscars-are-and-have-been-so-white us $56 \mathrm{~d} 12$ baee 4 b0bf0dab324790.

Reapropriate. (2014, April 17). What is Orientalisme and how is it also racism? Reapropriate.com. Retrieved from http://reappropriate.co/2014/04/ what-is-orientalism-and-how-is-it-also-racism/.

Said, W. (2000, Juni 1). Diary. London Review of Books. Vol 22 No.11. Retrieved from http:// www.lrb.co.uk/v22/n11/edward-said/diary.

Said, W. (2010). Orientalisme: menggugat hegemoni Barat dan mendudukan Timur sebagai subjek (Penj. Achmad Fawaid). Yogyakarta: Pustaka Pelajar.

Said, W. (2012). Dunia, teks dan (sang) kritikus (Penj. Sunaryono Basuki Ks). Bali: Bali Media Adhikarsa.

Schole, J. A. (December, 2002). What is globalization? the definition issue-again. CSGR Working Paper No. 109/02.

Sharp, G. (3 Maret 2010). "The submisive Asian stereotyoe: classy Asian ladies dating site”. The Society Pages. Retrieved from http:// thesocietypages.org/socimages/2010/03/03/ the-submisive-asian-stereotype-classy-asianladies-dating-site/.

Sheehan, K. B. (2004). Controversies in contemporary advertising. London: Sage Publications.

Syarifah. (2003). Kebertubuhan perempuan dalam pornografi. Jakarta: Kotakita. 


\section{Film}

Alladin (1992). Directed by Ron Clements \& John Musker. Producted by Walt Disney Feature Animation. Release by Walt Disney Picture.

Ally McBeal (1997). Comedy-Drama TV Series. Created by David E Kelley. Producted by Kayla Alpert et all., Production by $20^{\text {th }}$ Century Fox Television. Distributed by $20^{\text {th }}$ Television.

Charlie's Angel (2000) Directed by McG. Producted by Ridley Schott, Drew \& Nancy. Production Company by Flowers Film \& Tall Trees. Distributed by Columbia Pictures.

Doctor Strange (2016). Directed by Schott Derrickson. Based on Steve Ditko. Producted by Kevin Feige. Production Company Marvel Studios. Distributed by Walt Disney Studios \& Motions Picture.

Exiles: Edward Said (1988). TV Movie with Edward Said. Directed by Christopher Skyes. Production by BBC Two.

Exodus: God and King (2014) Directed by Alex Proyas. Producted by Peter Chernin etc all. Production Company by Chernin Entertainment, Schott Free Productions, Babieka, Volcano Films \& TSG Entertaintment. Distributed by $20^{\text {th }}$ Century Fox.

Flash Boys (2014). Directed by Rudin. Written by Michael Lewis. Producted by Elly Bush \& Scott Rudin. Production Company by Sony Pictures.

Fast Furious (2001-2017). Directed by Rob Cohen at all. Producted by Neal H Moritz, Van Diesel et all., Production Company by Original Film, Relativity Media, One Race Films \& Media Right Capital Distributed by Universal Pictures.

Gods of Egypt (2016). Directed by Alex Proyas. Producted by Basil Iwanyk \& Proyas. Production Company by Tunder Road Pictures \& Mystery Clock Cinema. Distributed by Summit Entertainment.

Gosh in the Shell (2017). Directed by Rupert Sanders. Producted by Avi Arad \& Steven Paul. Written by Jonathan Herman \& Jamie Moss. Production Company by DreamWorks Picture, Grosvenor Park Production \&. Distributed by Universal Pictures.

In The Shadow of The West (1985). Documentary film. Directed by Geoff Dunlop. Written and Narated by Edward Said. Producted by A VATV Production In Association with Kufic Films B.V.

Le Choucher De La Mariee (1896). Directed by Albert Kirchner. Producted Eugene Pirou. Distributed by Pseudonym.
Madam Butterfly (1932). Directed by Marion Gering. Written by David Belasco etc all. Producted by B.P. Schullberg. Distributed by Paramount Pictures.

Pearl Harbour (2001). Directed by Michael Bay. Producted by Tuchstone Picture \& Jerry Bruckheimer Films. Distributed by Walt Disney Studios Motion Picture.

The Palestinians" (1988). Two-part historical Television documentary prepared and presented by Edward Said and Ibrahim Abu Lughod. Directed by David Edgars. Produced by Taylor Downing. The Palestinians was a commissioned by Channel 4.

The World of Suzie Wong (1960). Directed by Richard Quine. Producted by Ray Stark. Written by John Patrick \& Paul Osborn. Production Company by MGM British Media. Distributed by Universal Pictures.

\section{Situs kencan online}

AreYouInterested.com, AsianDating.com, Match. com, AsianWomenDate.com, FilipinoCupid. com, Blossom.com, ThaiFriendly.com, ChnLove.com, JapanCupid.com, IDateAsian. com, KoreaCupid.com.

\section{Video Porno}

Vivid entertainment, Hustler, Playboy, Wicked picture, Red Light District, Uporn.com. 
